\section{Geology • Geography Dnipro university bulletin}

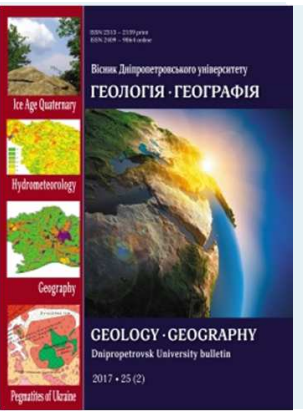

ISSN 2313-2159 (print) ISSN 2409-9864(online)

Dniprop. Univer.bulletin. Geology, geography., $25(2), 38-48$.

Journal home page: geology-dnu-dp.ua

\title{
Деякі аспекти паводкового схилового стокоутворення річок степової зони з урахуван- ням сучасних тенденцій формування опадів у межах Дніпропетровської області
}

\section{Д.О. Довганенко, А.С. Горб, С.М. Сердюк, О.В. Луньова, Л.В. Доценко}

Дніпровський національний університет імені Олеся Гончара, Дніпро, Украӥна, е-таil:ekodnu@i.ua

\section{Received 19 October 2017}

Received in revised form 30 October 2017

Accepted 15 November 2017 місце збільшення зволоження весняного сезону на фоні відсутніх змін у багаторічній динаміці. Встановлено придатність використання модуля r.sim.flow геоінформаційної системи QGIS для моделювання схилового стоку. Висвітлено основні результати інтерпретації числового експерименту з моделювання паводкового схилового стоку річок басейну р. Самара 3 урахуванням сучасного рівня землекористування в межах басейну річки. Запропоновано умовну шкалу та метод оцінювання впливу антропогенних факторів на формування поверхневого стоку малих річок. 3'ясовано роль та встановлено ступінь впливу підстильної поверхні басейну р. Самара на формування стоку. жень за опадами в межах території Дніпропетровської області. Охарактеризовано тенденцію формування опадів на цій території. Виявлено ознаки трансформації клімату області в бік тропічного типу. Визначено, що має

Резюме. Узагальнено результати багаторічних метеорологічних спостереКлючові слова: формування опадів, схилове стокоутворення, геоінформаиійні системи

\section{A study on flood runoff of the steppe river based on the modern trends of precipitation for- mation in Dnipropetrovsk region}

\author{
D. Dovhanenko, A. Horb, S. Serdiuk, O. Lunova, L. Dotsenko
}

\section{Oles Honchar Dnipro National University,Dnipro,Ukraine, e-mail:ekodnu@i.ua}

\begin{abstract}
This study aims to define the quantitative, qualitative and spatio-temporal parameters of atmospheric precipitation and the surface runoff of rivers within Dnipropetrovsk region using the example of Samara River. The specified goal is achieved taking into account the problems of keeping and development of the water resource potential in Dnipropetrovsk region. At the first stage the survey analyzes the features of precipitation formation in Dniproperovsk region. The analysis is based on climate data base which includes fifty-six years of measurements by nine meteorological stations. The entire monitoring period was divided into two parts in order to find the trends of precipitation formation. The initial processing allows to confirm that there is a rising of moistening at researched region, spatially from southwest to northwest, and according to the annual statistics the max precipitation shifts to warm seasons of the year. The winter season is characterized by longer period of precipitation, contrary to winter, there is no changes in summer. Moreover, there are the torrential rains in summer and the average rain intensity does not exceed $1 \mathrm{~mm}$ per min. The probability of events when the rain intensity is more than $1 \mathrm{~mm}$ per min is about $3 \%$. It was taking into account during the simulation. Nevertheless, one can see that rain type formation transformers into tropical one. The next main task of the research was to simulate the surface runoff of Samara River using the tool of QGIS- r.sim.water. The accuracy and reliability of the result correctness were confirmed by actual parameters of Vishnevy stream that placed in the territory of water-balance station Balzata (Moldova). As a result, the series of themes were created. It reflects the distribution of surface runoff parameters within Samara river basin during the warm season. In order to optimize the analyze the authors developed an estimation score system which is based on the influence of anthropogenic factors. Such solution allows to determine that the most problematic (from the "anthropogenic factors influence" point of view) regions are placed in the main river valley and at the southeast part of the Samara River basin. The rest part of the basin is characterized by minor or inessential influence of anthropogenic factors. The main anthropogenic factor that has the highest level of influence on the river runoff is an agricultural activity in the territory of Samara River basin. It affects the transformation time. The highest level of anthropogenic influence is determined in the middle of summer season, the lowest - in spring and autumn.
\end{abstract}


Вступ. Атмосферні опади - одні 3 основних складових кліматичних та гідрологічних ресурсів території, оскільки відіграють суттєву роль у фізико-географічних процесах і господарській діяльності людини. Зокрема в останньому випадку важливо знати всі можливі флуктуації кількості опадів на заданій території, адже від цього залежить ступінь ризику здійснення практично будь-якого виду господарської діяльності. Для району південного степу найбільш несприятливі в даному випадку інтенсивні зливові опади на початку літнього сезону. 3 іншого боку, подібні випадки повинні мати сприятливий ефект на гідрологічний режим та стан руслової мережі річок - повинна відбувається інтенсифікація рідкого та твердого стоку з території басейну, що сприятиме очищенню русловій мережі та збільшенню водності річки. Зазначені процеси перебувають у крихкій рівновазі між собою. Порушує рівновагу водного балансу території надмірна зарегульованість стоку річок.

На жаль, реалія сьогодення - це неможливість різкої перебудови або відмови від усього водогосподарського комплексу області та регіону в цілому на користь відновлення стоку річок. Цю проблему необхідно вирішувати послідовно, 3 повним розумінням того, що відбувається та буде відбуватися з водними об'єктами Дніпропетровської області в багаторічній перспективі.

3 урахуванням всього вищевикладеного, пріоритетними питаннями $є$ визначення актуальних характеристик опадоформування та як відбувається формування поверхневого схилового стоку з урахуванням цих характеристик та існуючого рівня господарської діяльності на території.

Труднощів із визначенням динаміки та просторово-часового режиму атмосферних опадів не повинно виникнути, оскільки база даних цієї величини достатньо містка та якісна (Horb \& Duk, 2006), (Babychenko, 1982 ), чого не можна сказати про ступінь вивченості схилового стоку річок області. Цей елемент водного режиму річок завжди був та залишається дотепер проблематичним для вивчення в натурних умоваx (Mitasova, Mitas, \& Brown, 2001), (Molchanov, 1960), (Nazarov, 1981). Очевидною першопричиною складності вивчення схилового стоку є його просторово-часова неоднорідність та відсутність відповідного інструментального забезпечення для спостережень за його характеристиками.

Зважаючи на це, зрозумілим буде твердження, що визначення схилового стоку завжди залишатиметься розрахунковою характеристи- кою, яку отримують шляхом розв'язання балансових рівнянь, або числовим моделюванням. Необхідно зазначити, що приблизно з початку 2000-х років помічається інтенсифікація розвитку геоінформаційних систем та модульних додатків до стандартних систем, що дозволяють візуалізувати формування схилового стоку та, відповідно, отримати його кількісні показники. Серед таких моделювальних систем можна назвати ArcGis, GIS Idrisi System, Quantum Gis, GIS GRASS та ін. Одна з цих систем буде використана для моделювання стоку р. Самара та аналізу просторового розподілу опадів.

Самара - типова та найбільша річка степової зони України. Її басейн розташований в межах одного 3 найбільш промислово і аграрно розвиненого регіону України. Близько $60 \%$ території басейну зайнята сільськогосподарськими угіддями, 17 \% - під елементами інфраструктури і населеними пунктами різного типу. На решті $23 \%$ території басейну розташовуються природні ландшафти (водні об'єкти, лісові масиви, незаймані ділянки степу). Стік річки зарегульований понад 1500 ставками різного призначення. Об'єм усіх ставків перевищує середньобагаторічний об'єм поверхневого стоку р. Самари 95\% забезпеченості. Транспортувальна здатність річок басейну р. Самара значно знижена. Зараз виконується низка проектів щодо відновлення русел річок Велика Терновка, Бик та ін.

У відповідності з визначеною актуальністю проблеми метою цієї роботи було визначення кількісних, якісних та просторово-часових характеристик атмосферних опадів та паводкового схилового стоку річок Дніпропетровської області, на прикладі р. Самара.

Матеріали і методи дослідження. Матеріали дослідження базуються на спостереженнях дев'яти метеорологічних станцій Дніпропетровщини за багаторічний період (1960 - 2016 рр.). Обрано саме повний ряд спостережень, оскільки була необхідність розкрити більш широкий спектр просторово-часових і динамічних характеристик опадів і в подальшому - схилового стоку. Для порівняння характеристик опадів матеріали спостережень поділені на два періоди: перший період (далі «I») - 1960 - 1990 pp. і другий (далі «ІІ») - 1991 - 2016 роки.

Характеристика опадів на території області була відображена за допомогою показників нерівномірності (1), середньоквадратичного відхилення (2), коефіцієнта зволоження (3) та коефіцієнта акумуляції (4). Крім цього, розраховано нормовані показники кількості опадів за ба- 
гаторічний, сезонний та місячний періоди та наведено інформацію про так звані екстремальні дощі, що мали місце на території області.

Показник періодичності (нерівномірності) опадів визначено за виразом (Hromov \& Mamontova, 1974):

$$
K_{n}=\frac{\sum\left|m_{i}-R / 12\right|}{R} \cdot 100 \%,
$$

де $R$ - річна сума опадів, $\sum\left|m_{i}-R / 12\right|-$ сума абсолютних величин різниці між кількістю опадів кожного місяця $m_{i}$ та $1 / 12$ частиною річної суми опадів.

Середньоквадратичне відхилення від норми опадів обчислене за виразом (Hromov \& Petrosyancz, 1994):

$$
\delta=\left(x_{n}-x_{i}\right) / d_{n},
$$

де $\delta$ - середньоквадратичне відхилення, $\left(x_{n}-\right.$ $\left.x_{i}\right)$ - різниця між найбільшою $x_{n}$ і найменшою $x_{i}$ компонентами ряду, $d_{n}-$ коефіцієнт, який за тривалості періоду спостережень 20 - 30 років становить 3,67.

Для обчислення зволоження використовується багато різних показників, зокрема М. I. Будико, М. М. Іванова, Г. Т. Селянінова та ін. У цій роботі для обчислення показника зволоження застосовано модифіковану форму гідротермічного коефіцієнта Г. Т. Селянінова та показник зволоження П. І. Колоскова (Hromov \& Petrosyancz, 1994)

$$
K_{3}=(W+R) /\left(0,18 \cdot \sum t\right),
$$

де $K_{3}$ - модифікована форма коефіцієнта зволоження; $W$ - запаси продуктивної вологи у метровому шарі грунту, мм; $R$ - кількість опадів за вегетаційний період, мм; $\sum t-$ сума активних температур $\left(>10^{\circ} \mathrm{C}\right)$ за вегетаційний період. У розрахунках прийняті вологозапаси, які відповідають 93,5 \% середньої вологоємності продуктивної вологи.

Зміну вологозапасів залежно від опадів характеризують коефіцієнтом акумуляції $K_{a}$, який дорівнює відношенню вологозапасів грунту на початку та в кінці періоду до суми опадів за цей період (Hromov \& Mamontova, 1974):

$$
K_{a}=\frac{W_{k}-W_{\Pi}}{\sum R} \cdot 100 \%
$$

де $W_{k}$ i $W_{\text {п }}$ - вологозапаси в метровому шарі грунту в кінці та на початку періоду, мм; $\sum R-$ сума опадів за той же період.

Останній показник досить часто використовується у гідрологічному моделюванні та гідрологічних розрахунках для з'ясування попереднього зволоження території басейну. В цілому дослідженні він використаний для корегування показників інфільтраційних втрат на кожен настуний проміжок часу моделювання схилового стоку.

Для виконання процедури моделювання був підготовлений комплект вхідних даних, який складався 3 двох блоків: перший блок описує умови землекористування із щомісячною динамікою параметрів рослинного покриву за теплий період року, другий характеризує змодельовані природні умови в межах цього ж басейну за теплий період року. Другий блок даних необхідна умова для визначення ступеня змін схилового стоку, оскільки інформації про характеристики природного схилового стоку для даної території не існує. Кожен із комплектів включає такі набори карт: цифрова модель рельєфу (ЦМР) місцевості; формування ефективних (стокоформувальних) опадів; параметри шорсткості різних типів поверхонь; висота рослинного покриву; середньомісячні показники гідрометеорологічних величин.

У процесі вивчення умов землекористування в межах басейну річки були використані серії супутникових знімків радіометра Landsat. Основний ряд знімків Landsat включає 28 знімків, які характеризують стан поверхні заданого регіону дослідження за період квітень - жовтень 2016 року. Визначення типів землекористування i дослідження динаміки рослинного покриву виконувалося із застосуванням таких підходів як: визначення спектральних показників типів поверхонь, візуальна ідентифікація за прямими i непрямими ознаками; розрахунок нормалізованого вегетаційного індексу (NDVI). Таким чином, були отримані карти землекористування i динаміки рослинного покриву в межах басейну p. Самара за період квітень - жовтень. Приклад однієї $з$ карт наведений на рисунку 1. 
УМОВНІ ПОЗНАЧЕННЯ:
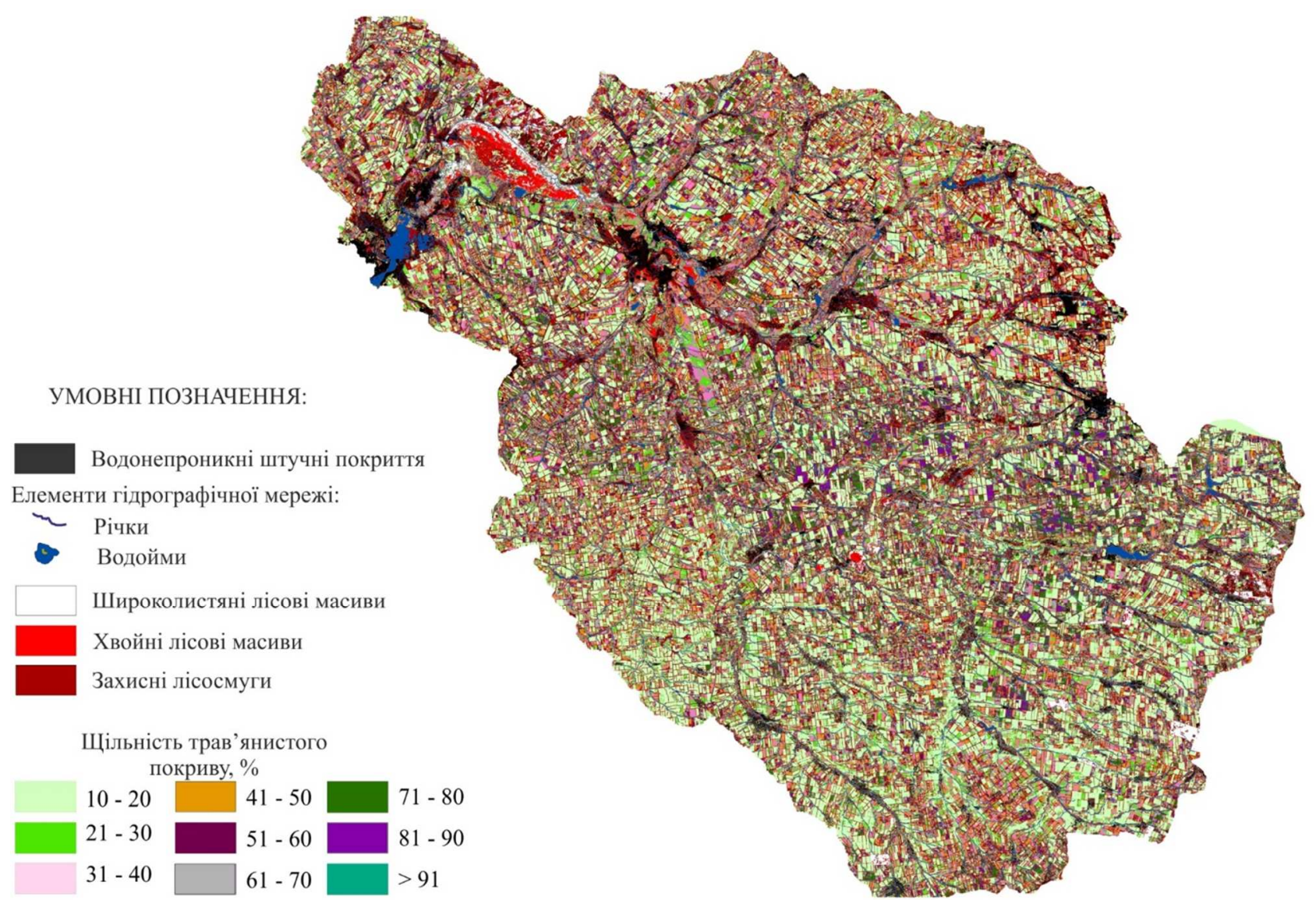

Рис. 1 Карта стану поверхні басейну р. Самара за липень 2016 року

Моделювання природних умов виконувалося шляхом екстраполяції показників степової рослинності 3 ділянок, на яких не здійснюється господарська діяльність. Допущення, зроблені під час побудови карт моделей природних умов, полягали в такому: рельєф території залишається без змін; процедури нівелювання проходили тільки штучно створені форми рельєфу (населені пункти, залізничні та автомобільні дороги, кар'єри і терикони); штучні водойми заміщувались ділянками руслової мережі; усі лісові масиви (за винятком протиерозійних та вітроламних насаджень) залишаються без змін; елементи інфраструктури заміщаються природною степовою рослинністю; грунтовий покрив території залишається без змін.

Після побудови карт типів землекористування і змодельованих природних умов, відповідно, по місяцях розрахункового періоду, були сформовані карти властивостей отриманих типів поверхонь: шорсткості, висоти і щільності рослинного покриву; грунтовий покрив залишено без змін.

Інфільтраційні властивості грунтового покриву і їх зміна за дієї рослинного покриву, інтенсивності дощу й орографічних умов були встановлені за довідковими даними (Cannata,
2003), (Chaplot, 2003), (Mitasova, Mitas \& Brown, 2001). Коефіцієнт Маннінга (коефіцієнт шорсткості) також установлений за довідковими даними і відповідно до визначених умов (Chaplot, 2003). Карти формування ефективних опадів складали за допомогою інструментів алгебри карт виходячи 3 водно-балансового співвідношення типу:

$$
i_{e}=R-I-E T
$$

де $R$ - інтенсивність опадів, мм/хв; $I$ - інфільтрація, мм/хв; $E T$ - евапотранспірація, мм/хв.

Розрахунки евапотранспірації проводилися з використанням інтегрованого в QuantumGIS модуля r.evapoPM (розробник М. Каната, МПI). Усі показники необхідні для розрахунку значення евапотранспірації, задавалися згідно з рекомендаціями М. Каннати (Cannata, 2003).

Безпосередньо для моделювання та подальшого аналізу розрахункових характеристик схилового стоку використано геоінформаційну систему Quantum GIS. Зокрема, моделювання стоку виконано за допомогою модуля r.sim.water, а аналіз та інтерпретацію отриманих 
даних - за допомогою інструментів просторової статистики і алгебри карт.

Достовірність та адекватність моделювання стоку за допомогою модуля r.sim.water перевірено шляхом співставлення розрахункових та фактичних значень стоку струмка Вишневий (водно-балансова

станція с. Балацата, Молдова). 3'ясовано, що середньоквадратичне відхилення складає 10,2
\%, що цілком прийнято згідно з існуючими нормативними документами.

Результати та їх аналіз. За результатами аналізу формування опадів на території Дніпропетровської області побудовано наскрізний графік середніх річних сум опадів на Дніпропетровщині, згладжений методом ковзного середнього за п’ятирічні періоди (рис.2).

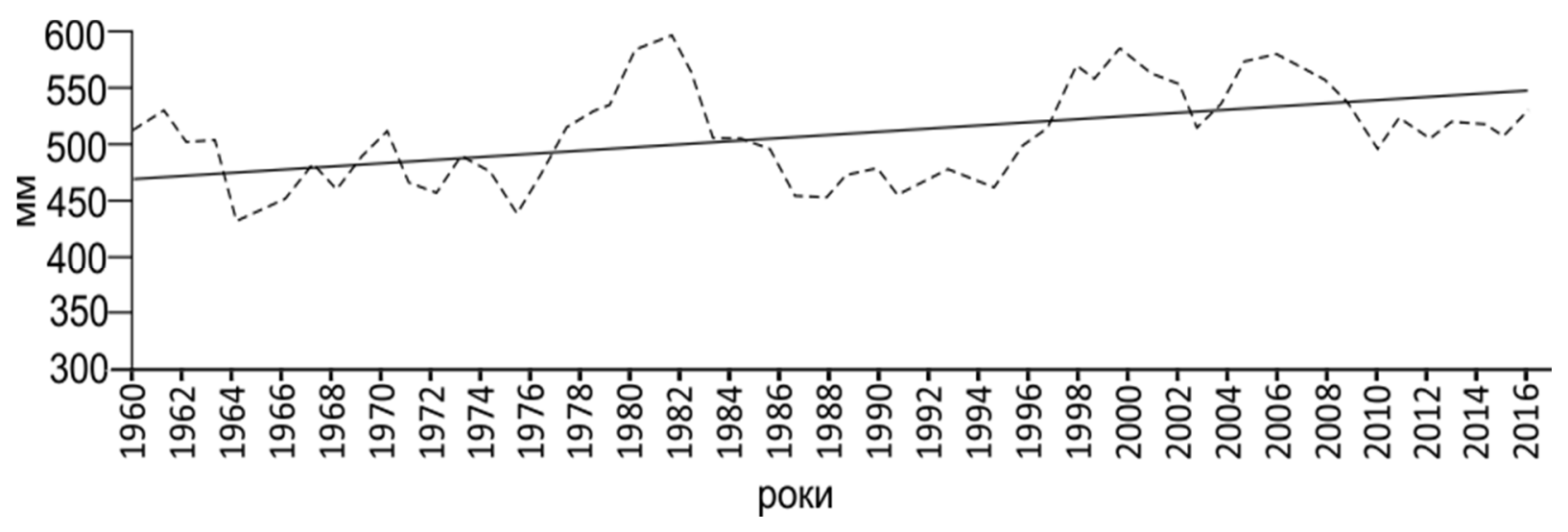

Рис. 2. Середня річна кількість опадів на Дніпропетровщині

На основі геометричного осереднення накреслено лінію тренду, яка свідчить, що за весь досліджуваний період спостерігається позитивний тренд кількості опадів, а середнє міжрічне збільшення їх кількості становить 1,4 - 1,5 мм за рік.

За увесь період спостережень можна виділити чотири цикли підвищеної кількості опадів, тривалістю 7, 12, 9 і 8 років і чотири цикли зниженої, тривалістю 9, 11 і 10 років, четвертий цикл ще триває. Середня тривалість циклів підвищеної і зниженої кількості опадів становить 9 - 10 років. За умов збереження позитивного тренду опадів можна припустити, що четвертий цикл зниженої кількості опадів закінчується.

За фактичними даними, середня річна кількість опадів у I періоді становить 492 мм, у II періоді - 528 мм (табл.1). 3 плином часу середня річна кількість опадів може суттєво змінюватись. Під час I періоду спостережень найбільша сума річних опадів 802 мм зафіксована на метеостанції Дніпропетровськ у 1960 році, найменша - 250 мм у 1988 році на метеостанції Нiкополь. У ІІ періоді максимальна річна кількість опадів відмічена метеостанціями Чаплине - 910 мм, Губиниха -812 мм, Дніпропетровськ -805 мм. На Дніпропетровщині середній річний максимум опадів 738 мм припав на 2004 рік. Мінімальна річна сума опадів 236 мм зафіксована у 2011 році метеостанцією Кривий Ріг.

Географічний розподіл і часові характеристики середньомісячних і середньорічних сум опадів по території області, зокрема, у другій половині XX століття наведені у працях авторів (Horb, 2006), (Horb \& Duk, 2006). Доповнити відомості можна порівнянням сезонних характеристик опадів I та II періодів спостережень (табл. 2). Аналіз порівняння показує, що середня сума зимових опадів II періоду становить 116 мм, що на 6 мм менше, ніж у I періоді; весняні опади, при сумі 129 мм, збільшилися на 17 мм; сума літніх опадів у II періоді становить 158 мм, що на 4 мм більше, ніж у I періоді; восени сума опадів II періоду дорівнює 125 мм, тобто на 16 мм більше від I періоду. Таким чином, основне збільшення опадів II періоду припало на весняні й осінні опади $(13,1$ і $16,8 \%$ відповідно 
Таблиця 1. Середні річні суми опадів (мм). Дніпропетровщина

\begin{tabular}{|c|c|c|c|c|c|c|c|c|c|c|}
\hline \multirow{3}{*}{$\begin{array}{l}\text { Період } \\
\text { спостере-ження }\end{array}$} & \multicolumn{9}{|c|}{ Метеостанції } & \multirow[b]{3}{*}{$\mathrm{R}_{\mathrm{cp}}$} \\
\hline & \begin{tabular}{|l} 
Губи- \\
ниха
\end{tabular} & $\begin{array}{l}\text { Коміса- } \\
\text { рівка }\end{array}$ & $\begin{array}{l}\text { Кривий } \\
\text { Ріг }\end{array}$ & $\begin{array}{l}\text { Лошка- } \\
\text { рівка }\end{array}$ & \begin{tabular}{|l|} 
Дніпро- \\
петровськ
\end{tabular} & $\begin{array}{l}\text { Павло- } \\
\text { град }\end{array}$ & Нікополь & $\begin{array}{l}\text { Синель- } \\
\text { никове }\end{array}$ & Чап-лине & \\
\hline & & & & & & & & & & \\
\hline I (1961 - 1990 pp.) & 531 & 491 & 463 & 480 & 506 & 507 & 450 & 474 & 525 & 492 \\
\hline II (1991 - 2016 pp.) & 556 & 519 & 441 & 514 & 560 & 536 & 479 & 559 & 592 & 528 \\
\hline Різниця & +25 & +27 & -22 & +34 & +54 & +29 & +29 & +85 & +67 & +36 \\
\hline
\end{tabular}

Територіально спостерігається загальна тенденція збільшення опадів із півдня та південного заходу на північ та схід.

Для характеристики частоти опадів використовують число днів 3 опадами, за день 3 якими приймають такий, коли впродовж доби випало $\geq 0,1$ мм опадів (Lipins'kyy, Dyachuk, Babichenko, Bondarenko, \& Rudishyna, 2003. ). Аналіз таблиці 3, де наведено середні місячні та

сезонні кількості днів з опадами, показує, що відмінності між I та II періодами не суттєві. В II періоді середня річна кількість днів 3 опадами зменшилась на 3,7 за рахунок літнього (-2,1 дня) та осіннього сезонів (3,8 дня). Зимового сезону кількість днів 3 опадами зросла на 2,2 дня, влітку ця характеристика однакова для обох періодів.

Таблиця 2. Середні сезонні суми опадів (мм). Дніпропетровщина

\begin{tabular}{|c|c|c|c|c|}
\hline \multirow{2}{*}{$\begin{array}{l}\text { Період } \\
\text { спостережень }\end{array}$} & \multicolumn{4}{|c|}{ Сезони } \\
\hline & Зима & Весна & Літо & Осінь \\
\hline I - $1961-1990 \mathrm{pp}$. & 122 & 112 & 154 & 104 \\
\hline II - $1991-2016$ pp. & 116 & 129 & 158 & 125 \\
\hline Різниця & -6 & +17 & +4 & +21 \\
\hline
\end{tabular}

Таблиця 3. Середня місячна, сезонна та річна кількість днів з опадами $\geq 0,1$ мм

\begin{tabular}{|c|c|c|c|c|c|c|c|c|c|c|c|c|c|c|}
\hline \multirow{3}{*}{ Період } & \multirow{3}{*}{$\begin{array}{l}\text { Характе- } \\
\text { ристика }\end{array}$} & \multicolumn{12}{|c|}{ Сезон, дні } & \multirow{3}{*}{$\begin{array}{l}\text { Cepe- } \\
\text { днє за } \\
\text { рік }\end{array}$} \\
\hline & & \multicolumn{3}{|c|}{ Зима } & \multicolumn{3}{|c|}{ Весна } & \multicolumn{3}{|c|}{ Літо } & \multicolumn{3}{|c|}{ Осінь } & \\
\hline & & XII & $\mathrm{I}$ & II & III & IV & $\mathrm{V}$ & VI & VII & VII & IX & $\mathrm{X}$ & XI & \\
\hline \multirow{2}{*}{ I } & $\begin{array}{l}\text { Середньо- } \\
\text { місячна }\end{array}$ & 13,4 & 13,5 & 11,4 & 10,9 & 10,2 & 10,3 & 11,3 & 9,3 & 8,1 & 8,5 & 8,8 & 11,0 & \\
\hline & $\begin{array}{l}\text { сезонна } \\
\text { сума }\end{array}$ & \multicolumn{3}{|c|}{38,3} & \multicolumn{3}{|c|}{31,4} & \multicolumn{3}{|c|}{28,7} & \multicolumn{3}{|c|}{28,3} & 126,7 \\
\hline \multirow{3}{*}{ II } & $\begin{array}{l}\text { Середньо- } \\
\text { місячна }\end{array}$ & 13,9 & 13,8 & 12,8 & 12,1 & 8,8 & 10,5 & 10,3 & 9,6 & 6,7 & 7,0 & 7,9 & 9,6 & \\
\hline & $\begin{array}{l}\text { сезонна } \\
\text { сума }\end{array}$ & \multicolumn{3}{|c|}{40,5} & \multicolumn{3}{|c|}{31,4} & \multicolumn{3}{|c|}{26,6} & \multicolumn{3}{|c|}{24,5} & 123,0 \\
\hline & $\begin{array}{l}\text { Різниця між I } \\
\text { i II }\end{array}$ & \multicolumn{3}{|c|}{$+2,2$} & \multicolumn{3}{|c|}{0,0} & \multicolumn{3}{|c|}{$-2,1$} & \multicolumn{3}{|c|}{$-3,8$} & $-3,7$ \\
\hline
\end{tabular}

Частота випадання опадів залежить не тільки від пори року, а й від географічного положення, рельєфу та орографії місцевості. Цей показник збільшується 3 півдня на північ Дніпропетровщини від 114 - 120 днів до 125 - 126 днів, а також у бік підніжжя Донецького кряжу - до 124 - 125 днів.

Інтенсивність опадів визначають із відношення суми опадів до тривалості цього періоду і виражають у мм/хв чи мм/год. Найінтенсивніші опади випадають 3 конвективних хмар у літній період. Причому за день 3 опадами випадає $6-9$ мм. В окремих випадках середній добовий максимум опадів $(20-25$ мм) може бути перевищеним у декілька разів. Відомий випадок зливи (Babychenko, 1982 ) 28 липня 1977 року в Дніпропетровську, під час якої лише за 2 години випало 120 мм опадів. Подібні випадки спостерігались у Павлограді та Кривому Розі в першій половині XX століття. Як правило, найбільші значення рясних злив мають інтенсивність 1,24 - 1,74 мм/хв. Але лише в $3 \%$ випадків інтенсивність може сягати 1 мм/хв (Horb, 2006).

Середня річна тривалість опадів збільшується $з$ південного заходу на північний схід і схід від 708 до 783 годин. У теплий період року можуть випадати тверді опади - град. Другий період спостережень відрізняється від першого більшою кількістю днів із градом. Якщо в $50-$ 80 роки XX ст. це явище природи відмічалось 1 
- 2 рази за рік, а в окремі роки його не було зовсім, то в останні $2-3$ десятиліття град випадає щорічно до $2-3$ разів за рік. Так, у 2008 році в с. Волоське Дніпропетровського району спостерігалось по одному випадку граду три місяці поспіль (IV, V, VI). На фоні потепління за останні 15 - 20 років у континентальному типі опадів помірних широт почала проявлятися нова риса, притаманна тропічним опадам.

Автори статті зафіксували декілька випадків короткочасних злив із купчастих хмар виду $\mathrm{Cu}$ cong, зокрема 30.06.2008 та 25.05.2016 років. У першому випадку - за температури повітря 26 ${ }^{\circ} \mathrm{C}$ і 6 балів хмар $\mathrm{Cu}$ cong, дві з яких переміщалися через пункт спостереження і дали короткочасні зливи середньої інтенсивності та тривалістю 4 і 6 хвилин. Другий випадок спостерігався на фоні 4 балів $\mathrm{Cu}$ cong i $\mathrm{Cu}$ med за температури повітря біля земної поверхні $28{ }^{\circ} \mathrm{C}$ та значної відносної вологості. Хмара виду $\mathrm{Cu}$ cong, нижня межа якої зафіксована на висоті приблизно 1 км, діаметр основи сягав близько 2 км, вершина хмари перебувала за позитивних температур.
Хмара пролилась дощем значної інтенсивності впродовж п'яти хвилин. В обох випадках інтенсивно розвивалась конвекція. Подібні випадки вже не поодинокі.

Крім кількісних характеристик і просторово-часового режиму опадів, споживачів різних галузей народного господарства цікавлять інші параметричні характеристики опадів, зокрема, періодичність, мінливість, акумуляція опадів і зволоженість території.

Матеріали спостережень I періоду характеризуються такими показниками періодичності опадів на Дніпропетровщині: середнє значення становить 51,8\%, мінімальне $28 \%$ відмічене метеостанцією Павлоград у 1975 році, максимальне 74 \% - Дніпропетровськ, 1972 рік.

У просторовому розподілі найбільша періодичність опадів 53 - $54 \%$ спостерігається на півдні та південному заході території області, зменшується у центральних районах до $49-50$ \% і збільшується до $51 \%$ на північ та схід від центра (табл. 4).

Таблиця 4. Періодичність опадів за метеостанціями Дніпропетровської області

\begin{tabular}{|c|c|c|c|c|c|}
\hline \multirow{2}{*}{ Метеостанція } & \multicolumn{2}{|c|}{ Період } & \multirow{2}{*}{ Метеостанція } & \multicolumn{2}{|c|}{ Період } \\
\cline { 2 - 3 } \cline { 5 - 6 } & I & II & I & ПІ \\
\hline Губиниха & 50,9 & 48,0 & Павлоград & 50,9 & 51,0 \\
\hline Комісарівка & 50,7 & 49,1 & Нікополь & 49,9 & 51,0 \\
\hline Кривий Ріг & 54,5 & 52,3 & Синельникове & 53,5 & 51,5 \\
\hline Лошкарівка & 53,4 & 53,5 & Чаплине & 52,6 & 51,8 \\
\hline Дніпропетровськ & 49,4 & 48,1 & Середнє & 51,8 & 50,7 \\
\hline
\end{tabular}

У II періоді спостережень показник періодичності опадів дещо змінився: середне значення склало 50,7 \% і на 1 - 2 \% зменшився показник на заході, центрі та південному сході обласTi.

Суттєвих відмінностей міжмісячної мінливості опадів в обох періодах спостережень не відбулося, середнє значення становило 51,6 i 50,9 відповідно до періодів. Міжрічні показники теж суттєво не відрізняються - 25,0 та 25,9. Але в просторовому розподілі мінливість опадів I періоду зменшувалась від периферійних районів до центральних, а в II періоді показники мінливості зростали від 22 до 28 з південного заходу на північний схід та схід території.

Середній показник зволоження $K_{3}$ у I періоді на Дніпропетровщині становить 25,6, мінімальний 12,6 (Нікополь 1967 рік). У ІІ періоді спостережень середній $K_{3}$ становить 25,8 , мінімальний 14,4, (Кривий Ріг, 2005 рік). У просторовому розподілі території Дніпропетровської області впродовж обох періодів спостережень коефіцієнти зволоження практично однакові й змінюються від 22 на півдні до 32 на півночі.

Основна кількість опадів акумулюється восени та холодного періоду року, до якого можна віднести також період сніготанення навесні. $\mathrm{y}$ теплий період опади швидко випаровуються із земної поверхні і транспірації рослин, тому акумуляційні запаси вологи нестабільні. Особливість осіннього періоду полягає в тому, що грунт ще не промерз, випаровування зменшується у зв'язку зі зниженням температури, тому волога вільно просочується в грунт. Взимку волога накопичується на поверхні промерзлого грунту й просочується в нього лише в період сніготанення. Виконані розрахунки коефіцієнта акумуляції показали, що восени акумулюється $54,6 \%$ опадів, у холодний період року $-33,9 \%$ (І період спостережень), 52, 6 \% - восени, 33,2 \% в холодну пору року (II періоду спостережень). Деяке зменшення коефіцієнта акумуляції опадів у кінці XX та на початку XXI ст. очевидно пов'язане із збільшенням випаровування, зумовленого потеплінням клімату. 
Таблиця 5. Повторюваність (\%) різної тривалості днів під час бездощових періодів, 2000 - 2016 роки.

\begin{tabular}{|c|c|c|c|c|c|}
\hline \multicolumn{7}{|c|}{ Повторюваність тривалості періодів (дні) } \\
\hline$\geq 10$ & $\geq 20$ & $\geq 30$ & $\geq 40$ & $\geq 50$ & $\geq 60$ \\
\hline 35,3 & 25,5 & 17,6 & 13,7 & 5,9 & 2,0 \\
\hline
\end{tabular}

Найбільші коефіцієнти акумуляції осінніх опадів притамані південно-західній та південній території 56 - $60 \%$, зменшуються на північ та схід до $50 \%$. Зимова акумуляція опадів зменшується у тому ж напрямку від 60 до 50 \% (I період спостережень). Акумуляція осінніх опадів II періоду змінюється з південного заходу на північ та схід від 62 до 48 \%; холодної частини року розподіл акумуляції опадів по території області інший: мінімальні значення $30-34 \%$ охоплюють майже всю центральну та північнозахідну частини території, максимальні $38-40$ $\%$ південь.

Для формування повної характеристики опадів у межах Дніпропетровської області та басейну р. Самара зокрема було визначено кількість бездощових періодів. У $50-70$ роки $\mathrm{XX}$ ст. на Дніпропетровщині кількість бездощових періодів тривалістю $>10$ днів не перевищувала п'яти, $>20$ днів - двох, періоди тривалістю $>90$ днів не спостерігались (Horb \& Duk, 2006). У таблиці 5 наведено повторюваність тривалості бездощових періодів теплої частини року за останні 16 років (2000 - 2016 рр.). Оцінка виконана за даними спостережень АМСЦ Дніпропетровськ. За досліджуваний період щорічно спостерігалось від 2 до 5 бездощових періодів.

Тривалі періоди бездощів'я пов'язані зі стаціонарними антициклонами, що тривалий час перебувають над центральними та східними районами Європи. Періоди без опадів спостерігаються як теплого, так і холодного періоду.

За результатами аналізу формування опадів на досліджуваній території було визначено основні характеристики дощів, що можуть провокувати формування паводків. Ці характеристики інтенсивності дощів використані для розрахунку кількості стокоформувальних опадів (Horb \& Duk, 2006).

За результатами проведених розрахунків отримано 448 карт, що відбивають формування стоку схилу в межах басейну р. Самара за теплий період року, починаючи з квітня і закінчуючи жовтнем.

Серед вказаної кількості карт 212 відбивають формування поверхневого стоку в «антропогенних умовах», 212 карт - в змодельованих природних умовах. Ще 24 карти відображають процес евапотранспірації в межах заданої території відповідно в умовах антропогенного навантаження i змодельованих природних умовах. Карти, що характеризують формування поверхневого стоку, діляться на дві категорії: до першої належать карти глибини потоку на схилі, до другої - карти витрати води на схилах. Розрахунок глибини і витрат потоку на схилах виконувався через певний проміжок часу, а саме через 1 годину для дощів із тривалістю до 20 годин і через 20 хвилин для дощів із високою інтенсивністю (до 2 мм/хв) і тривалістю до 1 години.

Порівняльний аналіз результатів моделювання стоку схилу виконувався за схемою:

1) визначення витрат потоку на схилі, що формуються за впливу окремих типів землекористування (відповідно для змодельованих природних і антропогенних умов);

2) визначення витрат потоку на схилі, які формуються за впливу антропогенних чинників;

3) порівняння показників витрат води в потоці на схилі, які формуються в антропогенних і змодельованих природних умовах;

4) складання карт міри впливу антропогенних чинників на формування стоку схилу в межах басейну р. Самара за теплий період року.

Пофакторний аналіз у межах басейнів 3-5$2 о$ порядків дозволив виявити, що вплив на формування стоку значною мірою залежить від стокоформувальних умов конкретного місяця. При цьому закономірних змін у процесі формування стоку схилу (порівняно 3 природними умовами) від одного сезону до іншого виявлено не було, оскільки аналізувалися стандартизовані умови.

За змодельованих природних умов має місце закономірність швидкості формування стоку схилу. Так, за весняно-літній період можна говорити про збільшення часу формування стоку в середньому на 120 секунд i, навпаки, за літньоосінній період відмічається зменшення часу на 90 - 100 секунд (для малих водозборів). В антропогенних умовах тенденція має протилежний характер. За весняно-літній період відмічається зменшення часу формування, за літньоосінній - збільшення на 20 - 50 секунд. Основним чинником при цьому виступає рослинний покрив на сільськогосподарських угіддях.

Елементи інфраструктури і сільськогосподарські угіддя без рослинного покриву в більшості випадків спричинюють збільшення витрат потоку на схилі. Особливо чіткий вплив указаних чинників простежується на схилах 3 
ухилом до $1^{\circ}$. Протиерозійні насадження і природні лісові масиви сприяють накопиченню $\mathrm{i}$ затримці стоку на схилі. У різні сезони за рахунок протиерозійних насаджень відмічається накопичення до $90 \%$ схилового стоку (залежно від розташування відносно напряму стікання).

Різниця між показниками глибини і витратами води на схилі, які сформувалися в умовах антропогенних чинників і змодельованих природних умовах у $80 \%$ випадків не перевищує $3 \%$. За впливу окремих чинників (наприклад, елементів інфраструктури) різниця між показниками змінюється від 0,1 до $20 \%$.

По сезонах теплого періоду року у формуванні стоку схилу були виявлені такі особливості:

1. За весняний сезон на $97 \%$ території басейну за впливу антропогенного навантаження формується в 1,3 рази більше об'єму стоку схилу порівняно зі змодельованими природними умовами. Різниця в показниках витрати води $\mathrm{i}$ глибини потоку у більшості випадків не перевищує $5 \%$. Викликано це переважною більшістю випадків нерівномірністю розвитку трав'яної рослинності в межах окремих басейнів річок. Так, у травні на сільськогосподарських угіддях рослинність розвинена дещо слабкіше, ніж на ділянках з природною рослинністю.

2. На початку літнього сезону відмічається протилежна ситуація. На 63 \% території басейну річки стік формується дещо повільніше. Тільки на відносно пологих ділянках (заплавні ділянки і міські території) показники стоку вищі змодельованих природних аналогів. Такі території складають 35 \% від загальної площі басейну. У липні кількість подібних зон збільшується до 45 \% від усієї території, що пов'язано зі зменшенням площ орних земель, покритих рослинністю. У серпні кількість областей в межах басейну, де відмічається збільшення показників стоку за рахунок антропогенних чинників складає 96 \%. Така ситуація зумовлена зменшенням площ земель, із рослинним покривом.
3.У вересні умови формування стоку схилу дещо подібні до весняного періоду. Зони, в межах яких показники стоку збільшуються за рахунок антропогенних чинників, складають 31 $\%$ від площі басейну річки. Цю ситуацію можна частково пояснити повторним заростанням сільськогосподарських угідь. У жовтні частка таких зон зростає до $69 \%$, що викликано завершенням урожайної кампанії і підготовкою сільськогосподарських угідь до наступного сезону.

Для узагальнення умов формування схилового стоку по території басейну р. Самара прийнято рішення інтерпретувати ступінь трансформованості стоку річки в бальній оцінці. Так, у разі виявленого збільшення або зменшення показників стоку за впливу одного конкретного фактора призначався один бал. Оскільки кількість факторів, що аналізувалися в дослідженні, становила 10, максимальна оцінка антропогенного впливу становила 10 балів.

За результатами такої інтерпретації побудовано серію карт, що відображають умовний ступінь трансформації стоку в межах басейну річки Самара. На рисунку 3 наведено приклад такої карти, на якій позначено зони (басейни) 3 різною мірою антропогенного впливу на формування схилового стоку за теплий період.

Згідно 3 отриманими картами найбільша міра антропогенного впливу на формування стоку схилу відмічається в частинах басейну річки з високим рівнем урбанізації - Дніпропетровський, Новомосковський, Павлоградський райони Дніпропетровської області й Олександровський, Добропільський, Червоноармійський, Великоновоселківський райони Донецької облаcri.

Отриманий картографічний матеріал має значний потенціал для використання у сферах водного господарства, охорони довкілля, гідрологічних і гідроекологічних досліджень. Також отримані результати можуть служити основою для розробок методологічної і нормативної бази у вказаних сферах господарської і наукової діяльності. 

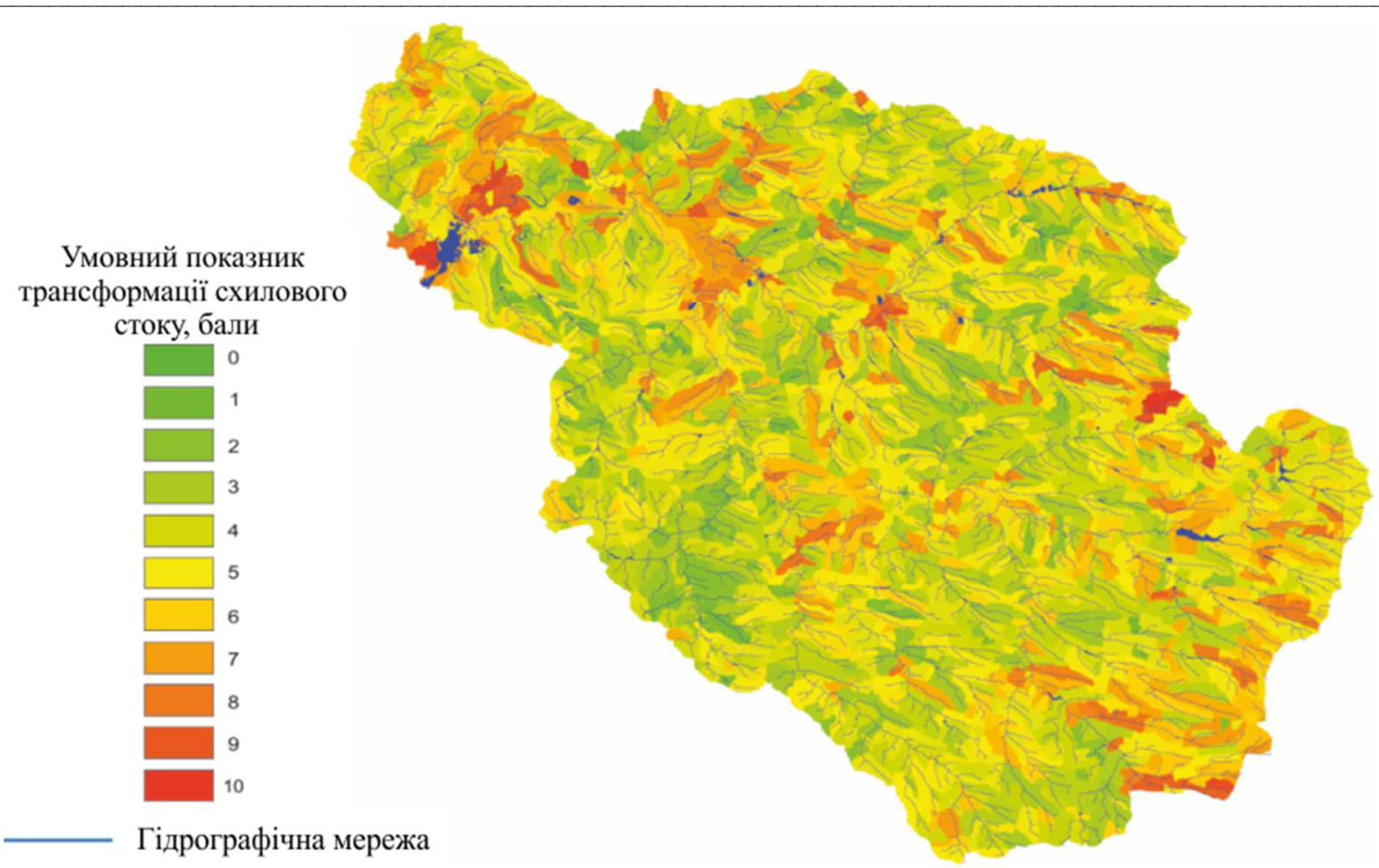

Рис. 3. Ступінь впливу антропогенних факторів на формування схилового стоку (липень 2016 р.)

Висновки та рекомендації. За результатами виконаного дослідження сформовано такі висновки.

- Аналіз результатів спостережень свідчить про суттєві просторово-часові та міжрічні зміни атмосферних опадів. Відповідно I періоду спостережень (1960 - 1990 рр.) кількість опадів II періоду (1991 - 2016 рр.) збільшилась на 7 \%. Найбільша середня річна кількість опадів на Дніпропетровщині відмічена у XX ст. - 689 мм (1966 р.), у XXI ст. - 738 мм (2004 р.). Абсолютний максимум середніх річних опадів 910 мм відмічений метеостанцією Чаплине (1977р.). Абсолютний мінімум річних сум опадів 236 мм відмічений метеостанцією Кривий Ріг у 2011 році.

- У територіальному відношенні найменшою кількістю опадів характеризується південно-західна частина області, найбільшою північні та східні райони.

- Середній показник періодичності опадів становить 51,8 \%, показник мінливості 50,9 51,6 , показник зволоження 25,6, осінній показник акумуляції становить 54,6, зимовий - 33,2.

- Річна кількість днів з опадами залежить від географічної широти і рельєфу та орографії місцевості й змінюється від 115 днів у південних районах до 132 у північних.

- Річна тривалість опадів збільшується 3 південного заходу на північний схід і схід від 713 до 782 годин.
- У ХХІ столітті зросла кількість бездощових періодів до 2 - 4 за рік, а також збільшилось число днів із градом до $2-3$ на рік. Найбільша кількість днів із випаданням снігу припадає на січень і лютий: 9, 4 і 8, 3 дня відповідно. У ті ж місяці спостерігаються 1 - 2 дні із заметілями з випаданням снігу.

- Згідно з результатами моделювання стоку схилу з'ясовано, що в межах території басейну р.Самара має місце трансформація стоку різної спрямованості. Збільшення показників стоку у більшості випадків спостерігається в межах пологих ділянок поверхні басейну. Такі зони належать до: гирлової ділянки, середньої і частково верхньої течії р. Самара, східної і південно-східної частини басейну річки.

- 3'ясовано, що основний чинник, від якого залежить збільшення або зменшення розрахованих показників стоку - це рослинний покрив сільськогосподарських угідь. Це пов'язано $з$ варіативністю просторової динаміки розвитку рослинного покриву впродовж вегетаційного періоду. Так, за весняний сезон за впливу антропогенних чинників у гідрографічну мережу надходитиме більше стоку зі схилів, ніж у разі змодельованих природних умов. На початку літнього сезону ситуація дещо вирівнюється, що пов'язано зі співставністю показників розвитку рослинності за реальних і змодельованих природних умов. Під кінець літнього сезону за участі антропогенних чинників формується біль- 
ший об'єм стоку, ніж за змодельованих природних умов.

- 3 урахуванням виявлених особливостей можна дійти висновку, що вплив різнопланових антропогенних чинників (зокрема, розораність території) на формування паводкового схилового стоку р. Самара $є$ співставним, а в деяких випадках -переважаючим фактором, 3 тенденційними змінами опадоформування.

\section{Бібліографічні посилання}

Babychenko, V. N. (1982 ). Klymat Dnepropetrovska [The climate of the Dnipropetrovsk]. L.: Gy’dromety`zdat (in Russian), 342.

Cannata, M. A. (2003). GIS embedded approach for Free \& Open Source Hydrological Modelling. Milano.

Chaplot, V. A. (2003). Yves Le Bissonnais Runoff Features for Interrill Erosion at Different Rainfall Intensities, Slope Lengths, and Gradients in an Agricultural Loessial Hillslope. Soil Science Society of America Journal , 844851.

Horb, A. S. (2006). Osoblyvosti i zminy rezhymu atmosfernykh opadiv na Dnipropetrovshchyni [Features and changes of the regime of atmospheric precipitation in the Dnipropetrovsk region]. Visnyk Dnipropetrovs'koho universytetu, ser. «Heolohiya. Heohrafiya, 8587.

Horb, A. S., \& Duk, N. M. (2006). Klimat Dnipropetrovs'koyi oblasti [The climate of the Dnipropetrovsk region]. D.: Vydavnytstvo DNU (in Ukrainian).

Hromov, S. P., \& Mamontova, L. Y. (1974). Meteorology'chesky'j slovar' [Meteorological dictionary]. L.: Gy'dromety'zdat (in Russian).

Hromov, S. P., \& Petrosyancz, L. M. (1994). Meteorology'ya $y^{\prime} \quad$ kly'matology'ya [Meteorology and Climatology]. M.: MGU (in Russian).

Lipins'kyy, V. M., Dyachuk, V. A., Babichenko, V. M., Bondarenko, Z. S., \& Rudishyna, S. F. (2003. ). Klimat Ukrayiny [The climate of Ukraine]. K.: Vyd-vo Rayevs'koho (in Ukrainian).

Mitasova, H., Mitas, L., \& Brown, W. M. (2001, September). Multiscale Simulation of Land Use Impact on Soil Erosion and Deposition Patterns. Sustaining the Global Farm, 1163-1169. Retrieved from http://www2.gis.uiuc.edu.

Molchanov, A. A. (1960). Gidrologicheskaya rol lesa [Hydrological role of forest]. M. : AN SSSR (in Russian).

Nazarov, G. V. (1981). Gidrologicheskaya rol pochvyi [Hydrological role of soil]. L.: Nauka (in Russian). 